http://dx.doi.org/10.6113/TKPE.2012.17.1.85

$$
\begin{gathered}
\text { 순간전압강하 보상을 위한 저가의 승압형 } \\
\text { 단상 인버터 시스템의 설계 및 구현 } \\
\text { 이승용, 홍순찬 }
\end{gathered}
$$

\title{
Design and Implementation of Low Cost Boost Type Single-Phase Inverter System for Compensation of Voltage Sag
}

\author{
Seung-Yong Lee ${ }^{1}$, and Soon-Chan Hong $^{\dagger}$
}

\begin{abstract}
In this paper, a 300[W] class boost type single-phase inverter system which can compensate voltage sag on source side is designed and implemented. This system is a two-stage conversion system composed of a boost converter and a PWM inverter. If the voltage sag has appeared at the point of common coupling, the boost converter would be operated to compensate it. The boost converter and the inverter were constructed on single smart power module(SPM) to implement low cost system. The system is designed for that the THD of ouput voltage is below 5[\%]. Finally, the validity of the design for the inverter system is verified by both simulations and experiments.
\end{abstract}

Keywords : Voltage Sag, Inverter, Boost Converter, Voltage Sag Compensation

\section{1. 서 론}

산업의 급속한 발달로 외란에 민감한 부하의 사용이 증가하고 있으며, 전력품질에 대한 관심이 높아지고 있 다. 특히 순간전압강하의 발생 빈도가 높으며, 크기는 $0.1[\mathrm{pu}] \sim 0.4[\mathrm{pu}]$, 지속시간은 60[cycle] 이하인 순간전압 강하가 가장 많이 발생하고 있다 ${ }^{[1]}$.

순간전압강하 관련 규격으로는 SEMI(Semiconductor Equipment and Materials International) F47-0706, IEC 61000-4-11, IEEE std. 493-2007 등이 있다. 이 중에서 SEMI F47-0706이 가장 엄격하게 규정하고 있는데, 순 간전압강하가 발생하여 입력전압이 $0.5[\mathrm{pu}]$ 일 경우에는 $200[\mathrm{msec}], 0.7[\mathrm{pu}]$ 일 경우에는 $500[\mathrm{msec}], 0.8[\mathrm{pu}]$ 일 때 는 1 [sec] 동안 시스템이 정상동작할 것을 규정하고 있 다 $^{[2]}$.

그림 1과 같이 공통결합점(PCC : Point of Common Coupling)에 같이 접속되어 있는 대형 부하가 기동할 때 인버터의 입력단에 순간전압강하가 발생할 수 있다 ${ }^{[3]}$.

Paper number : TKPE-2012-17-1-12

† Corresponding Author : schong@dku.edu, School of Electronics and Electrical Engineering, Dankook Univ.

${ }^{1}$ Department of Electronics and Electrical Engineering, Dankook University

Manuscript received Dec. 26, 2011; accepted Jan. 8, 2012
구체적인 예를 들면 대용량 전동기 시스템에서 전동기 가 기동할 때나 $\mathrm{X}$ 선 시스템에서 촬영할 때에는 순간적 으로 큰 전력을 소모하므로 입력단에 순간전압강하가 발생한다 ${ }^{[4]}$. 이때 같은 전원을 사용하는 보조장치의 구 동장치나 제어회로가 이 순간전압강하에 의해 오동작을 하거나 심한 경우에는 동작을 멈출 수도 있다. 배터리를 사용하는 경우라도 배터리의 속응성이 낮아 직류전원단 에 순간전압강하가 발생하게 된다.

단상 인버터를 $\mathrm{d}-\mathrm{q}$ 축 변환을 통해 제어하는 경우, 좌표변환을 위해 추가적인 가상의 신호가 필요하다. 이 를 위해 phase shifter와 같은 추가적인 회로의 구현이 필요하다. 또한 정지좌표계를 동기좌표계로 변환하고 제 어동작을 다시 정지좌표계로 변환하여야 하기 때문에 연산시간 지연과 오차가 발생한다. 이로 인해 저가형 프 로세서에서 구현하기가 쉽지 않다.

본 논문에서는 PR(Proportional-Resonant) 제어기를

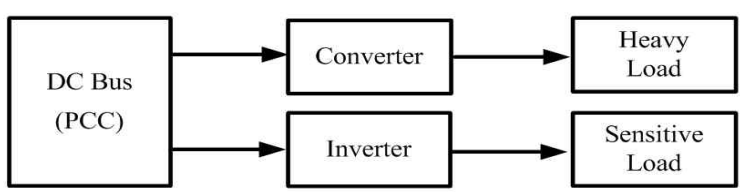

그림 1 순간전압강하 발생 예

Fig. 1 An example of the generation of voltage sag 
사용한 저가의 승압형 단상 인버터 시스템을 설계하고 구현하고자 한다. 제안한 시스템은 동일한 직류단을 주 된 회로와 같이 전원으로 사용하는 부속 구동장치,제어 회로 등에 순간전압강하가 발생하는 경우에도 안정적인 전력을 공급해야 하는 보조 전원장치이다. 순간전압강하 에 대한 내성은 SEMI F47-0706을 기준으로 하며 시스 템 출력전압의 $\mathrm{THD}$ 는 $5[\%]$ 미만을 목표로 한다.

\section{2. 승압형 단상 인버터 시스템 설계}

\section{1 승압형 단상 인버터 시스템}

그림 2는 순간전압강하를 보상할 수 있는 승압형 단 상 인버터 시스템이다 ${ }^{[5]}$. 시스템은 입력전압 $V_{S}$ 를 승압 하는 부스트 변환기, 직류링크단 전압 $V_{d c}$ 를 입력으로 하는 인버터와 바이패스 다이오드 $D_{2}$ 로 구성되어 있다.

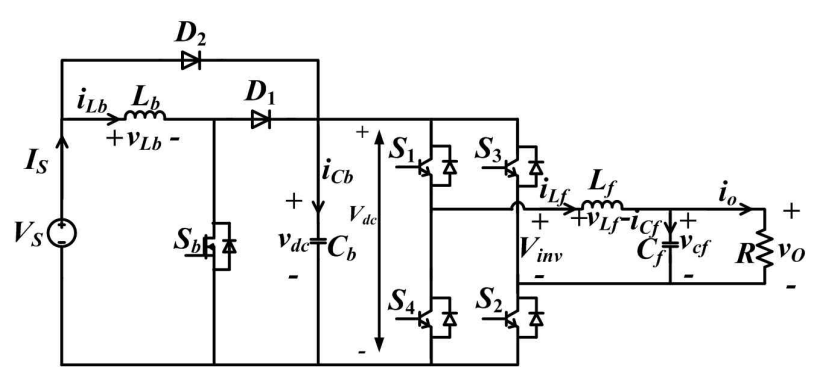

그림 2 승압형 단상 인버터 시스템

Fig. 2 Boost type single-phase inverter system

본 논문에서는 전원전압의 공칭값이 $\mathrm{DC} 380[\mathrm{~V}]$ 이고 시스템의 출력이 $220[\mathrm{Vrms}], 60[\mathrm{~Hz}]$ 이며 부스트 변환기 및 인버터의 스위칭 주파수가 $20[\mathrm{kHz}]$ 인 $300[\mathrm{~W}]$ 급 시스 템을 대상으로 하여 설계한다.

입력전압에 순간전압강하가 발생하여도 $V_{d c}$ 가 공칭값 의 $0.9[\mathrm{pu}]$ 인 $342[\mathrm{~V}]$ 이상일 경우에는 인버터가 $D_{2}$ 를 통 해 전력을 공급받도록 한다. 그러나 순간전압강하의 크 기가 $0.1[\mathrm{pu}]$ 를 초과하는 경우에는 부스트 변환기를 동 작시켜 직류링크단 전압을 $0.9[\mathrm{pu}]$ 로 승압한다. SEMI F47-0706을 적용하면 시스템이 보상해야 할 최대 순간 전압강하의 크기는 $0.5[\mathrm{pu}]$ 이다.

\section{2 제어기 설계}

\subsection{1 부스트 변환기 제어기}

부스트 변환기의 제어기는 그림 3과 같다. 직류링크단 전압을 기준전압 신호와 비교한 후 PI 제어된 값을 전 류제어기를 통해 제어한다 ${ }^{[5]}$.

\subsection{2 인버터 제어기}

인버터 제어기로는 정지좌표계에 직접 적용이 가능하 고 정상상태 오차를 제거할 수 있는 $\mathrm{PR}$ 제어기를 사용 한다.

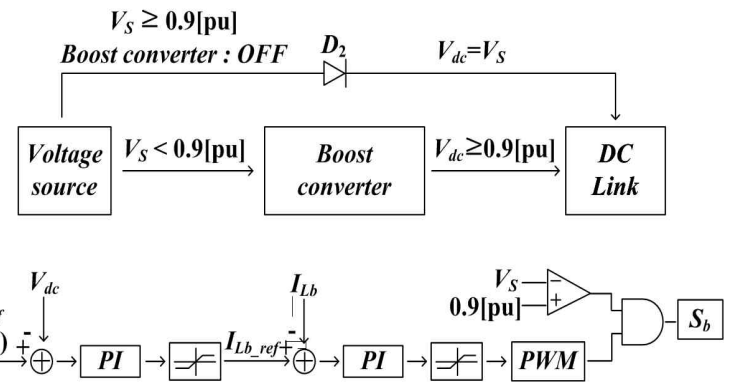

그림 3 부스트 변환기 제어도

Fig. 3 Control diagram of boost converter

1 차 저역통과필터를 적용한 $\mathrm{PR}$ 제어기의 전달함수에 서 공진 각주파수 $\omega_{0}$ 와 차단 각주파수 $\omega_{c}$ 의 관계가 $\omega_{0} \gg \omega_{c}$ 이면, $\mathrm{PR}$ 제어기의 전달함수는 식 (1)과 같다 ${ }^{[6]}$.

$$
H_{P R}(s)=K_{P}+\frac{K_{I} \omega_{c} s}{s^{2}+2 \omega_{c} s+\omega_{0}^{2}}
$$

그림 4 는 본 논문에서 사용한 인버터용 $\mathrm{PR}$ 제어기이 다. 출력전압 기준신호 $v_{o}^{*}$ 와 출력전압 $v_{o}$ 를 비교하여 비 례기 $K_{P v}$ 와 공진기 $G_{R v}$ 로 구성된 $\mathrm{PR}$ 전압제어기로 전 압을 제어한다. 그리고 $\mathrm{PR}$ 전압제어기의 출력 $i_{O}^{*}$ 와 출 력전류 $i_{O}$ 를 비교하여 비례기 $K_{P i}$ 와 공진기 $G_{R i}$ 로 구성 된 $\mathrm{PR}$ 전류제어기를 통해 출력전류를 제어한다. $\mathrm{PR}$ 제 어기를 통해 제어된 값을 인버터에 PWM 신호로 인가 한다.

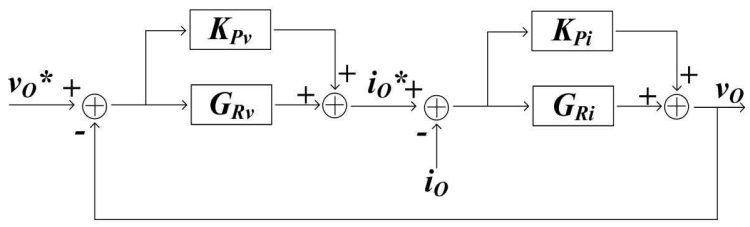

그림 4 인버터 제어도

Fig. 4 Control diagram of inverter

식 (1)의 $\mathrm{PR}$ 제어기 전달함수에서 공진항은 식 (2)와 같다. 이는 전압제어기 및 전류제어기 각각의 공진기에 해당하는 전달함수이다.

$$
G_{R}(s)=\frac{K_{I} \omega_{c} s}{s^{2}+2 \omega_{c} s+\omega_{0}^{2}}
$$

식 (3)으로 표현되는 tustin method ${ }^{[7]}$ 를 식 (2)에 대입 하여 $Z^{-}$변환하면 식 (4)와 같이 표현된다.

$$
s=\frac{2(z-1)}{T(z+1)}
$$




$$
\frac{Y(z)}{X(z)}=\frac{b_{0}+b_{1} z^{-1}+b_{2} z^{-2}}{1+a_{1} z^{-1}+a_{2} z^{-2}}
$$

여기서 $T$ 는 샘플링 시간이며, $A=4+4 \omega_{c} T+\omega_{0}^{2} T^{2}$ 이 라 하면 $\quad b_{0}=2 K_{I} \omega_{c} T / A, \quad b_{1}=0, \quad b_{2}=-2 K_{I} \omega_{c} T / A$, $a_{1}=\left(-8+2 \omega_{0}^{2} T^{2}\right) / A, a_{2}=\left(4-4 \omega_{c} T+\omega_{0}^{2} T^{2}\right) / A$ 이다.

식 (4)를 시간영역에서 표현하면 식 (5)와 같다.

$$
y(t)=b_{0} x(t)+b_{2} x(t-2)-a_{1} y(t-1)-a_{2} y(t-2)
$$

식 (5)를 직접 연산하여 공진제어기를 구현할 수 있 다. 하지만 고정소수점 연산을 하는 마이크로프로세서의 경우 연산 오차가 발생하게 되고 ${ }^{[8]}$, 특히 저가의 16 비트 인 경우 오차가 더 크게 발생하여 제어기가 불안정해질 수 있다. 이러한 문제점을 해결하는 방법으로 direct form 변환이 있다. Direct form에는 direct form I, transposed direct form I, direct form II, transposed direct form II의 네 종류가 있다 ${ }^{[8]}$. 본 논문에서는 고속 의 연산이 가능한 그림 5의 transposed direct form II 방식을 사용하여 식 (4)를 연산한다. 여기서 $y(n), q(n)$, $r(n)$ 은 식 $(6)$ 식 (8)과 같다.

$$
\begin{aligned}
& y(n)=b_{0} x(n)+q(n-1) \\
& q(n)=b_{1} x(n)-a_{1} y(n)+r(n-1) \\
& r(n)=b_{2} x(n)-a_{2} y(n)
\end{aligned}
$$

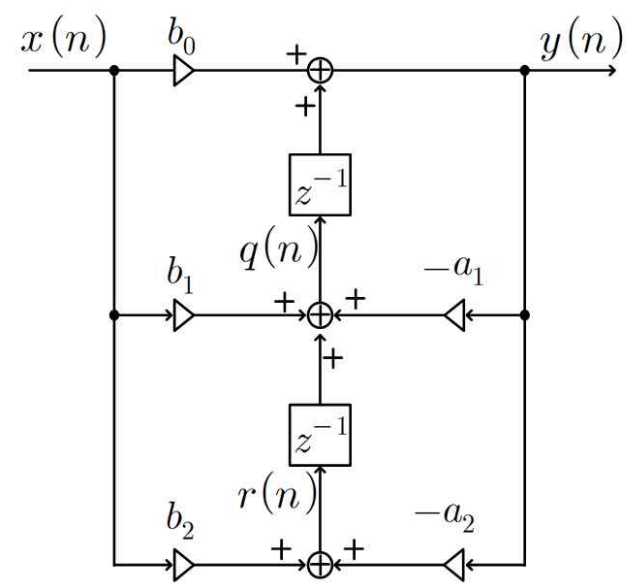

그림 5 Transposed direct form II 블럭도

Fig. 5 Block diagram of transposed direct form II

\section{3 하드웨어 설계}

저가의 승압형 단상 인버터 시스템을 구현하기 위해 그림 6과 같이 하드웨어를 구성하였다. 전력소자는 Fairchild사의 600[V], 30[A] 정격인 FSBB30CH60을 사 용하였다. 이 소자는 3상용 SPM으로서 3개의 암을 가 지고 있다. 이 중 1 개의 암을 사용하여 부스트 변환기를 구현하고 다른 2 개의 암으로 단상 인버터를 구현하였다. $\mathrm{SPM}$ 에서 왼쪽에 있는 암의 상단에 있는 스위칭 소자의 게이트 단자를 그림 6과 같이 처리하면 이 스위칭 소자 는 항상 오프상태가 되며 부스트 변환기의 $D_{1}$ 으로만 동 작한다.

제어기의 출력은 PWM 발생기를 통해 각 스위칭 소

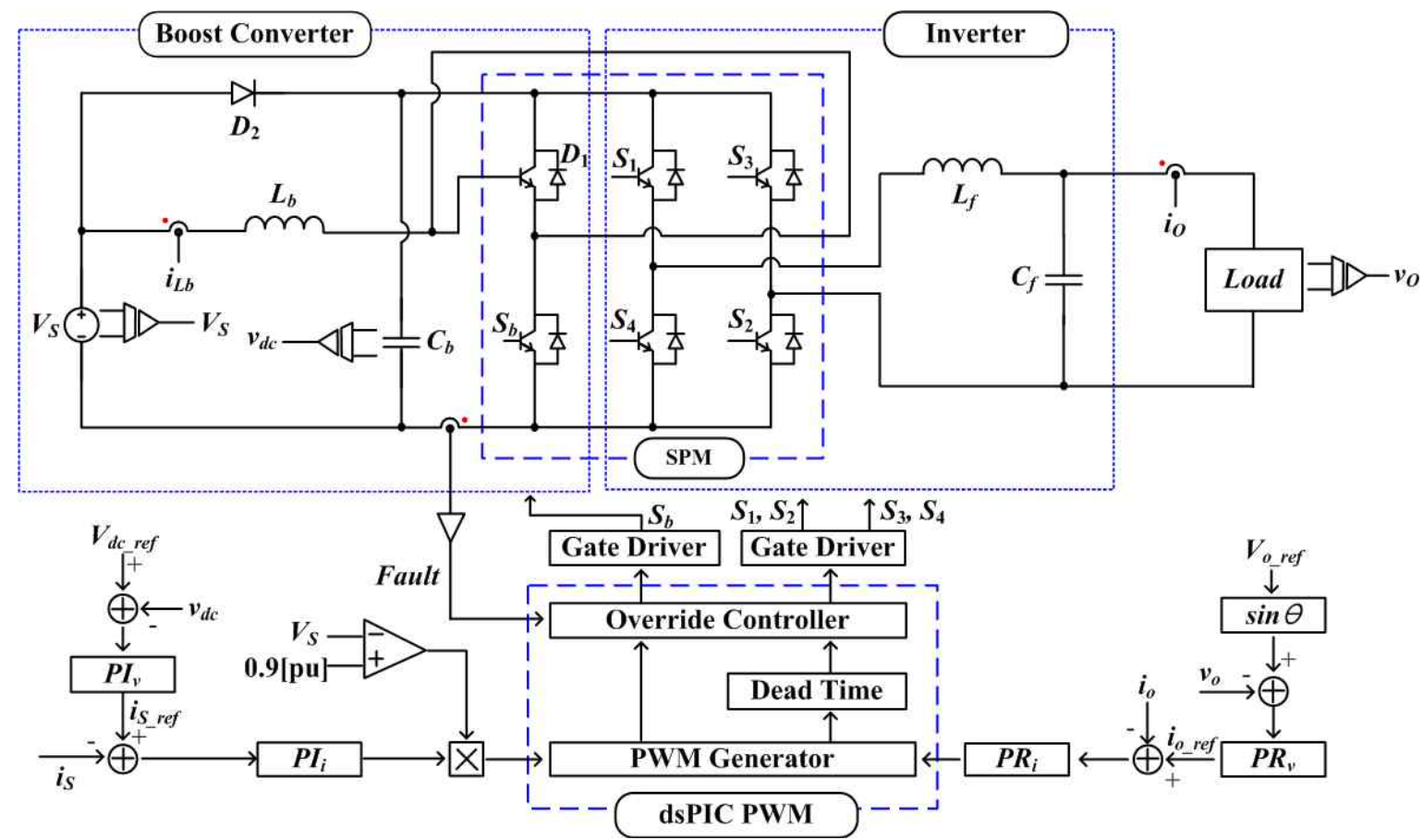

그림 6 승압형 단상 인버터 시스템의 구조 및 제어블록도

Fig. 6 Structure and control block diagram of boost type single-phase inverter system 
자에 인가되는 게이트 신호를 생성한다. 인버터의 게이 트 신호는 dead time controller를 사용하여 암단락을 방 지하며, override controller는 과전류가 흐르거나 이상 동작이 발생하면 게이트 신호를 차단하여 소자를 보호 하는 역할을 한다.

부스트 변환기는 입력전압이 $0.9[\mathrm{pu}]$ 인 $342[\mathrm{~V}]$ 미만인 경우에만 동작한다. 입력단 전압 $V_{S}$ 의 변동범위를 $0.5[\mathrm{pu}]$ 로 하였을 때 듀티비 $D$ 를 구하면 0.444 이다. 이 에 따라 듀티비 범위를 $0.05 \leq D \leq 0.5$ 로 제한한다.

인버터의 출력 $P_{O}$ 는 $300[\mathrm{~W}]$ 이다. 이 전력은 직류링크 단 전압이 $342[\mathrm{~V}]$ 일 때에도 공급할 수 있어야 한다. 인 버터에서 손실이 없다고 가정하고 부스트 변환기 출력 단의 등가저항 $R_{e q}$ 를 구하면 390[S]이다.

부스트 변환기에서 인덕터 $L_{b}$ 에 흐르는 전류가 연속 이기 위한 최소 인덕터 값 $L_{b, \min }$ 은 식 (9)와 같다 ${ }^{[9]}$.

$$
L_{b, \min }=\frac{D(1-D)^{2} R_{e q}}{2 f}
$$

식 (9)를 이용하여 $L_{b, \mathrm{~min}}$ 을 구하면 $596[\mu \mathrm{H}]$ 이지만, 본 논문에서는 여유를 두어 $2.4[\mathrm{mH}]$ 로 설계한다.

커패시터 $C_{b}$ 의 값은 최악의 경우를 상정하여 선정한 다. 시스템의 출력단 전압 및 전류의 실효값을 $V_{O}$ 및 $I_{O}$ 라 하면 커패시터가 공급해야할 최대 에너지는 $\sqrt{2} V_{O} \times \sqrt{2} I_{O}=2 P_{O}$ 이다. 이 에너지를 $C_{b}$ 에서만 공급 한다고 가정하고 직류링크단 전압의 변동량을 $\triangle V_{d c}$, 인 버터의 스위칭 주파수를 $f_{i}$ 라 하면 식 (10)이 성립한다.

$$
\frac{1}{2} C_{b} V_{d c}^{2}-\frac{1}{2} C_{b}\left(V_{d c}-\triangle V_{d c}\right)^{2}=2 P_{O} \frac{1}{f_{i}}
$$

식 (10)에서 $\left(\triangle V_{d c}\right)^{2}$ 항을 무시하고 직류링크단 전압 맥동률을 $K_{V d c}=\Delta V_{d c} / V_{d c}$ 라 하면 식 (10)은 식 (11)과 같이 정리된다.

$$
K_{V d c}=\frac{2 P_{O}}{V_{d c}^{2} f_{i} C_{b}}
$$

$K_{V d c}$ 가 직류링크단 전압 맥동률 설정값인 $K$ 이하가 되기 위한 커패시터 $C_{b}$ 의 범위는 식 (12)와 같다.

$$
C_{b} \geq \frac{2 P_{O}}{V_{d c}^{2} f_{i} K}
$$

직류링크단에서 인버터가 정상동작하는 최소전압인 $342[\mathrm{~V}]$ 를 고려하고 전압 맥동률을 $0.1[\%]$ 로 하면 $C_{b}$ 의 최소값은 $256[\mu \mathrm{F}]$ 이다. 본 논문에서는 여유를 두어 940 $[\mu \mathrm{F}]$ 으로 선정하였다.
마지막으로 인버터 출력단의 고조파를 제거하기 위한 $\mathrm{LC}$ 필터를 설계한다. 통상 $\mathrm{LC}$ 필터의 차단주파수 $f_{c}$ 는 식 (13)과 같이 인버터 스위칭 주파수 $f_{i}$ 의 $1 / 10$ 이하로 선정한다 ${ }^{[10]}$. 본 논문에서는 $f_{c}=1[\mathrm{kHz}]$ 로 선정하였다.

$$
f_{c}=\frac{1}{2 \pi \sqrt{L_{f} C_{f}}} \leq \frac{f_{i}}{10}
$$

필터 인덕터는 부하와 직렬로 접속되기 때문에 그 임 피던스가 부하단 임피던스보다 작아야 한다. 본 논문에 서 선정한 인덕터 $L_{f}$ 는 $11[\mathrm{mH}]$ 이며, 커패시터 $C_{f}$ 는 2.2 $[\mu \mathrm{F}]$ 이다.

\section{4 소프트웨어 설계}

마이크로프로세서로는 Microchip사의 dsPIC33 계열인 dsPIC33FJ128MC706을 사용하였다. 이 프로세서는 16비 트이며 고성능이면서 $\mathrm{DSP}$ 에 비하여 가격이 저렴하다.

프로세서에서 사용한 알고리즘의 주요 내용은 그림 7 과 같다. 프로그램은 주 프로그램과 인터럽트 서비스 루 틴으로 구성된다. 주 프로그램에서는 CPU의 내부 하드 웨어 및 인터럽트 벡터를 초기화하고 제어변수를 초기 화한 후에 PWM을 시작한다. 무한 반복되는 메인루프에 서는 스위치의 입력을 확인하고 내부 제어변수와 측정 변수를 $\mathrm{DAC}$ 를 통하여 출력하며 직렬통신의 송신 등을 수행한다.

인터럽트 서비스 루틴에는 PWM 인터럽트, DMA 인 터럽트, 직렬통신 수신 인터럽트가 있다. PWM 인터럽 트 서비스루틴에서는 부스트 변환기와 인버터 각단의

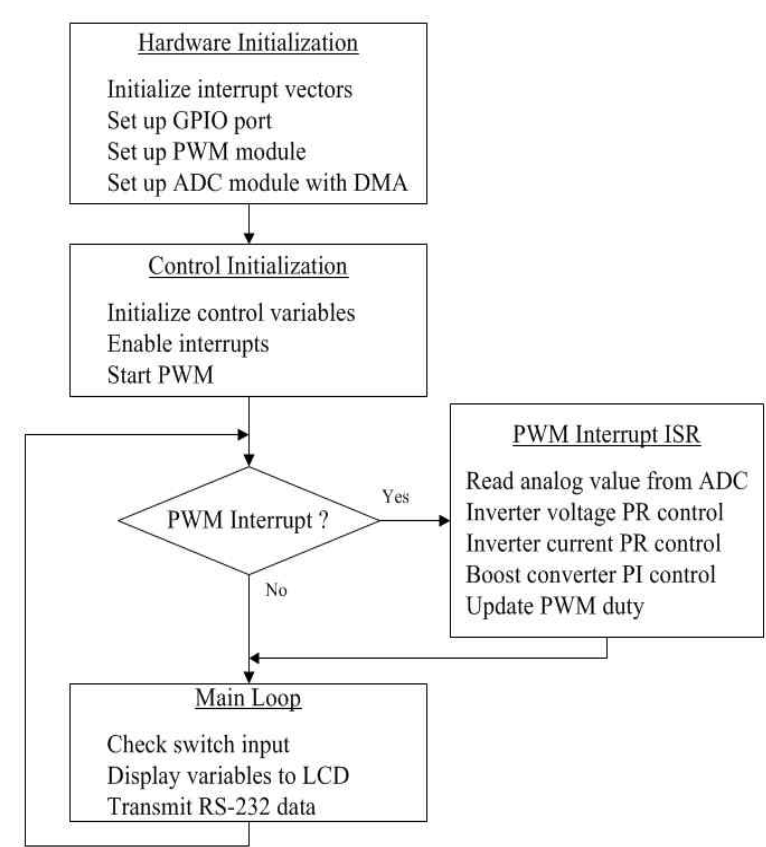

그림 7 프로세서에서의 프로그램 알고리즘

Fig. 7 Algorithm of program on processor 
전압 및 전류값을 검출하고, 부스트 변환기와 인버터에 대한 디지털 제어 알고리즘을 수행하여 직류링크단 전 압 및 출력전압을 제어한다. 전압과 전류값은 내장된 $\mathrm{ADC}$ 에서 디지털 값으로 변환되며 $\mathrm{DMA}$ 를 통해 $\mathrm{SRAM}$ 에 저장된다.

\section{3. 시뮬레이션}

설계한 파라미터를 적용한 시스템을 $\mathrm{PSIM}$ 을 사용하 여 시뮬레이션하였다. PSIM의 C-block을 사용하여 제 어기를 디지털로 구현하였으며 시뮬레이션 파라미터는 표 1 과 같다.

표 1 시뮬레이션 파라미터

Table 1 Simulation parameters

\begin{tabular}{|c||c|}
\hline 출력전압 $v_{O}$ & $220[\mathrm{Vrms}]$ \\
\hline 부스트 변환기 인덕터 $L_{b}$ & $2.4[\mathrm{mH}]$ \\
\hline 직류링크단 커패시터 $C_{b}$ & $940[\mu \mathrm{F}]$ \\
\hline 인버터 필터 인덕터 $L_{f}$ & $11[\mathrm{mH}]$ \\
\hline 인버터 필터 커패시터 $C_{f}$ & $2.2[\mu \mathrm{F}]$ \\
\hline 부스트 변환기 스위칭 주파수 $f_{b}$ & $20[\mathrm{kHz}]$ \\
\hline 인버터 스위칭 주파수 $f_{i}$ & $20[\mathrm{kHz}]$ \\
\hline
\end{tabular}

그림 8은 저항부하일 경우에 대해 전원전압에 순간전 압강하가 발생하였을 때 본 논문에서 설계한 시스템이 SEMI F47-0706에 규정되어 있는 사항을 만족하는지를 확인하기 위해 시뮬레이션한 결과이다. 그림에서 위 파 형은 전원전압 $V_{S}$ 와 직류링크단 전압 $V_{d c}$ 이고 아래 파 형은 인버터의 출력전압 $v_{O}$ 이다.

그림 8(a)는 순간전압강하의 지속시간이 가장 긴 경우 로서 $0.2[\mathrm{pu}]$ 크기의 순간전압강하가 발생했을 때 시스 템이 1 [sec] 동안 정상동작함을 확인한 파형이다. 그림 8(b)는 순간전압강하의 크기가 가장 큰 경우로서 $0.5[\mathrm{pu}]$ 크기의 순간전압강하가 $200[\mathrm{msec}]$ 동안 지속된 경우이 다. 그림 8로부터 입력전원에 순간전압강하가 발생하여 도 부스트 변환기가 직류링크단 전압을 승압하여 인버 터의 출력전압이 일정하게 유지되고 있음을 확인할 수 있다.

그림 9는 본 논문에서 제안한 시스템이 R-L부하에서 도 정상적으로 동작함을 확인하기 위해 $100[\Omega]$ 저항과 $350[\mathrm{mH}]$ 인덕터를 사용하여 시뮬레이션한 결과이다. SEMI F47-0706에서 순간전압강하가 가장 큰 $0.5[\mathrm{pu}]$ 일 때의 결과로서 $\mathrm{R}-\mathrm{L}$ 부하에서도 시스템의 출력전압이 일 정하게 유지되고 있음을 확인할 수 있다.

그림 10 은 부하변동에 대한 시뮬레이션 결과이다. 출 력전류 $i_{O}$ 는 100 배 확대하여 나타내었다.

그림 10(a)는 저항부하일 경우로서 부하저항을 320

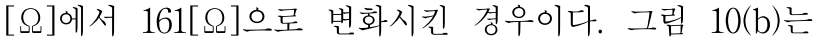
$\mathrm{R}-\mathrm{L}$ 부하일 경우로서 $\mathrm{R}=330[\Omega], \mathrm{L}=350[\mathrm{mH}]$ 에서 $\mathrm{R}=$ $100[\Omega], \mathrm{L}=350[\mathrm{mH}]$ 로 변화시킨 경우이다. 그림 10 의 두 그림으로부터 $\mathrm{R}$ 부하 및 $\mathrm{R}-\mathrm{L}$ 부하에서 부하가 변하여 출 력전류 $i_{O}$ 가 증가하여도 시스템의 출력전압 $v_{O}$ 가 일정 함을 알 수 있다.

\section{4. 실험 결과 및 검토}

설계한 승압형 단상 인버터 시스템의 유용성을 입증 하기 위해 300[W]급 시스템을 그림 11과 같이 구성하고 실험하였다. 실험 파라미터는 시뮬레이션 파라미터와 동 일하다.

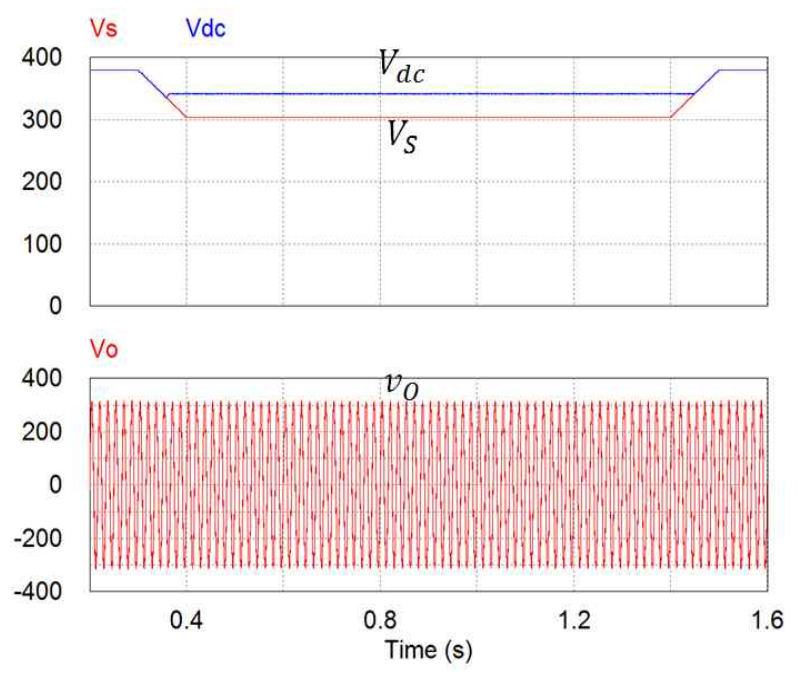

(a) $0.2[\mathrm{pu}]$ 순간전압강하

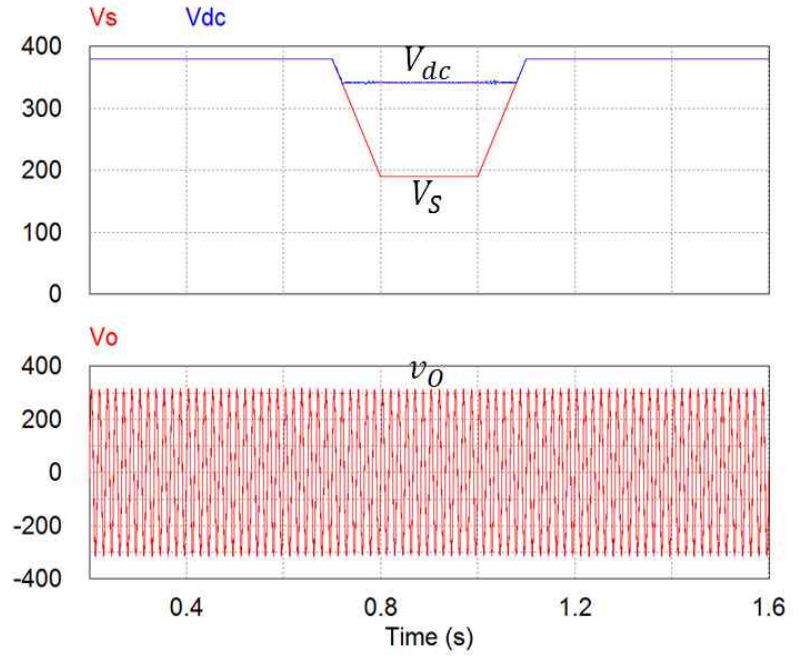

(b) $0.5[\mathrm{pu}]$ 순간전압강하

그림 8 순간전압강하 시뮬레이션 결과 (저항부하)

Fig. 8 Simulation results of voltage sag (R load) (Horizontal : $200 \mathrm{msec} /$ div., Vertical : $100 \mathrm{~V} /$ div.) 


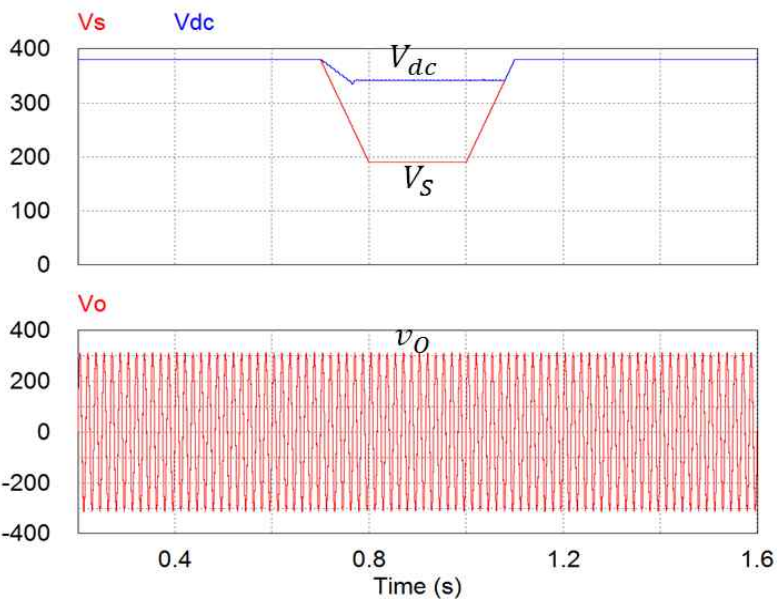

그림 $90.5 \mathrm{pu}$ 순간전압강하 시뮬레이션 결과 (R-L부하)

Fig. 9 Simulation results of 0.5 pu voltage sag (R-L load)

(Horizontal : $200 \mathrm{msec} /$ div., Vertical : $100 \mathrm{~V} /$ div.)

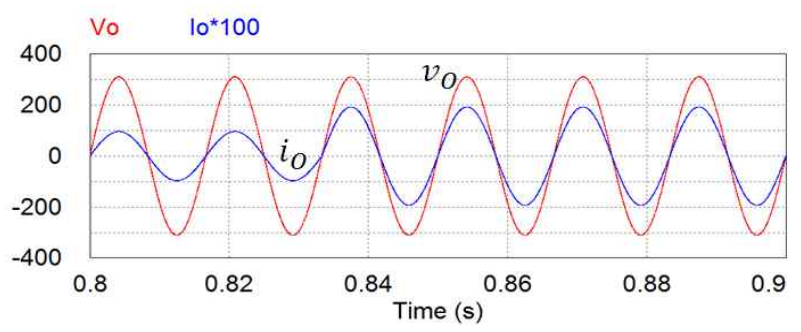

(a) 저항부하

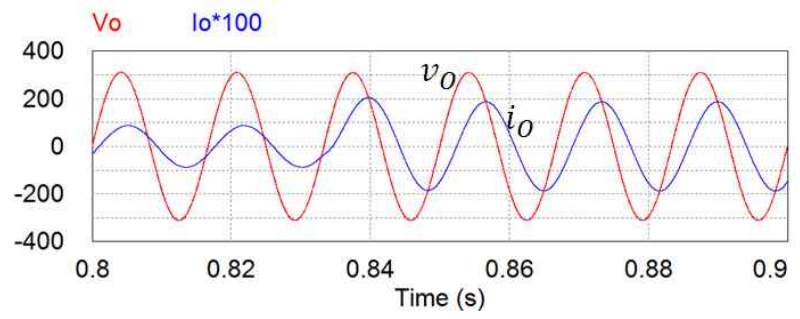

(b) $\mathrm{R}-\mathrm{L}$ 부하

그림 10 부하가 변화할 때의 시뮬레이션 결과

Fig. 10 Simulation results for load change

(Horizontal : $20 \mathrm{msec} /$ div., Vertical : $100 \mathrm{~V} /$ div.)

그림 12 는 저항부하에서 순간전압강하가 발생한 경우 를 실험한 결과로서 그림 $12(\mathrm{a})$ 는 $0.2[\mathrm{pu}]$ 크기의 순간전 압강하가 $1[\mathrm{sec}]$ 동안 지속된 경우이고, 그림 $12(\mathrm{~b})$ 는 $0.5[\mathrm{pu}]$ 크기의 순간전압강하가 $200[\mathrm{msec}]$ 동안 지속된 경우이다. 순간전압강하가 발생하여도 시스템이 SEMI F47-0706 규격을 만족하여 시스템의 출력전압이 일정하 게 유지됨을 알 수 있다.

그림 13 은 $100[\Omega]$ 저항과 $350[\mathrm{mH}]$ 인덕터로 구성된 $\mathrm{R}-\mathrm{L}$ 부하일 때 실험한 결과이다. $0.5[\mathrm{pu}]$ 크기의 순간전 압강하가 200[msec] 동안 지속된 경우이며 $\mathrm{R}-\mathrm{L}$ 부하에 서 순간전압강하가 발생하여도 출력전압이 일정하게 유
지됨을 알 수 있다.

그림 14 는 설계한 시스템의 동특성을 확인하기 위하 여 부하를 변화시킨 경우이다. 그림 14(a)는 저항부하일

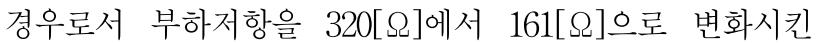
경우이다. 그림 $14(\mathrm{~b})$ 는 $\mathrm{R}-\mathrm{L}$ 부하일 경우로서 $\mathrm{R}=330[\Omega]$,

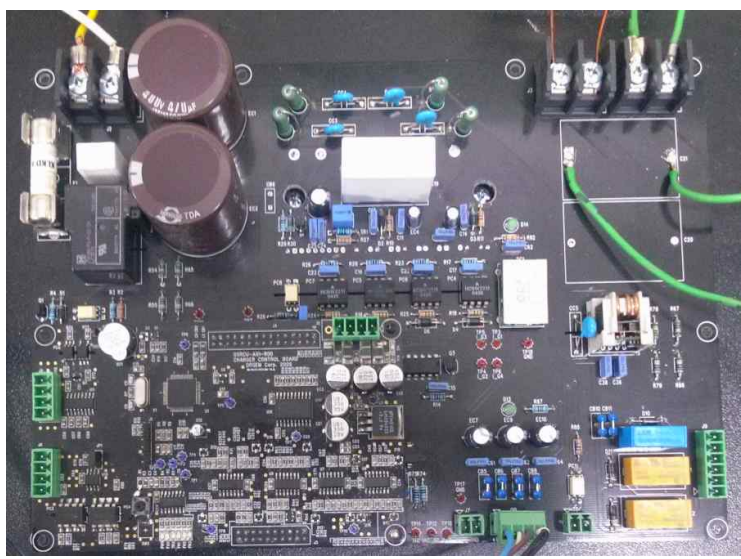

그림 11 실험장치

Fig. 11 Experimental setup

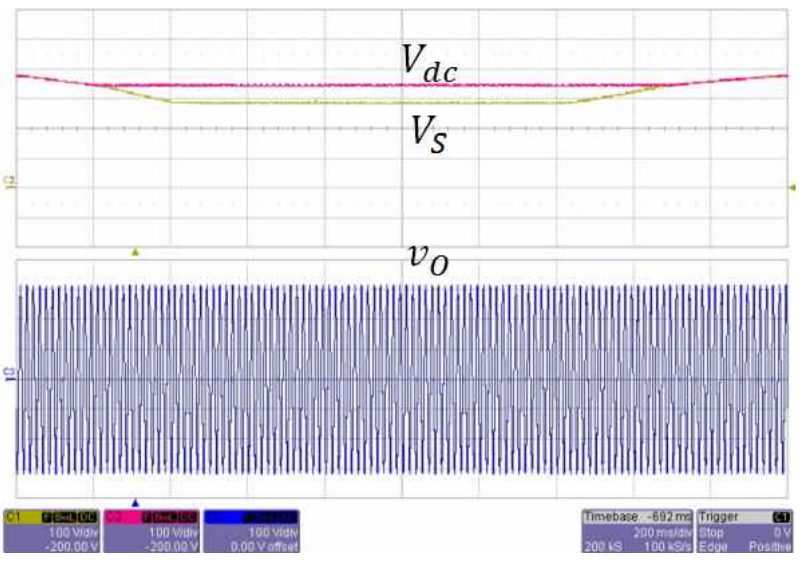

(a) $0.2[\mathrm{pu}]$ 순간전압강하

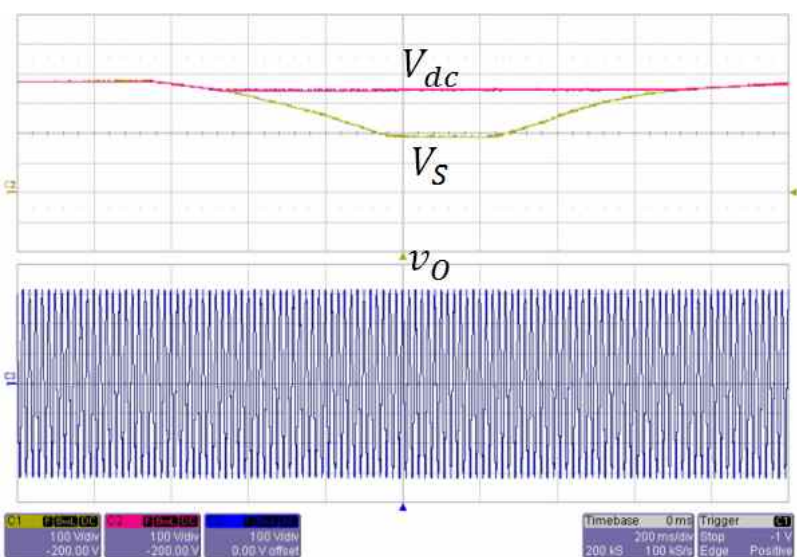

(b) $0.5[\mathrm{pu}]$ 순간전압강하

그림 12 순간전압강하 실험 결과 (저항부하)

Fig. 12 Experimental results of voltage sag (R load) (Horizontal : $200 \mathrm{msec} /$ div., Vertical : $100 \mathrm{~V} /$ div.) 


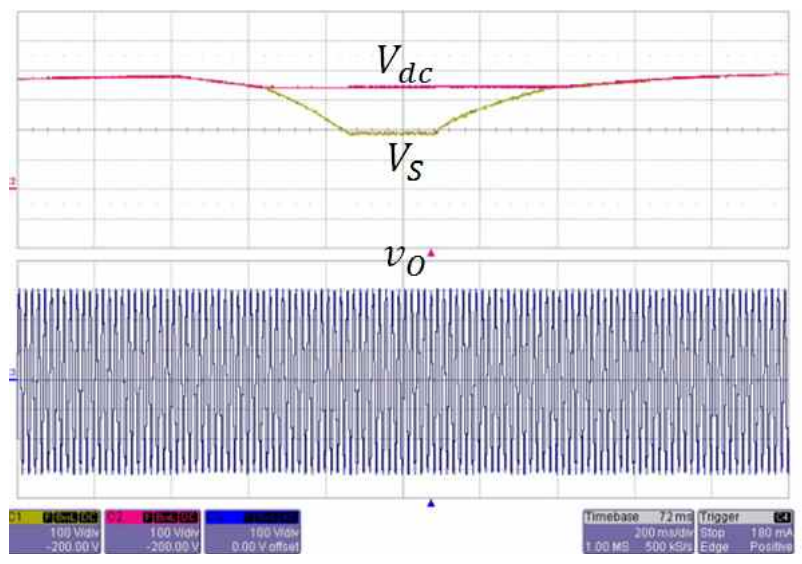

그림 $13 \quad 0.5 \mathrm{pu}$ 순간전압강하 실험 결과 (R-L부하)

Fig. 13 Experimental results of $0.5 \mathrm{pu}$ voltage sag ( $\mathrm{R}-\mathrm{L}$ load)

(Horizontal : $200 \mathrm{msec} /$ div., Vertical : $100 \mathrm{~V} /$ div.)

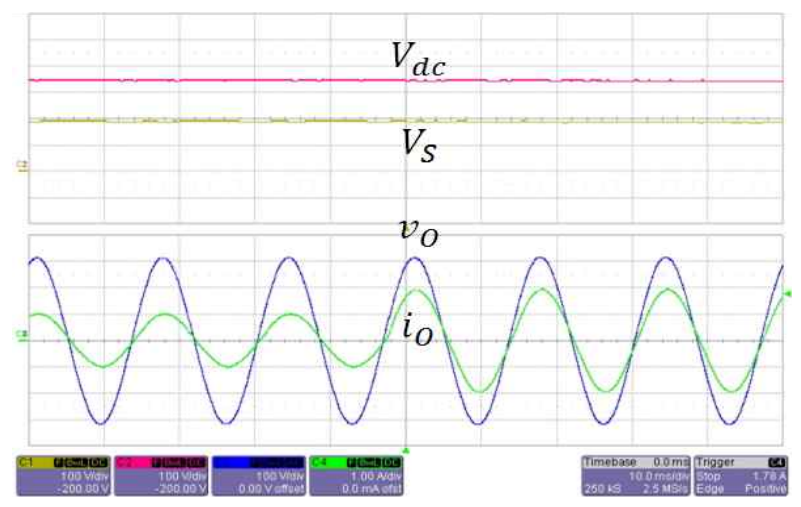

(a) 저항부하

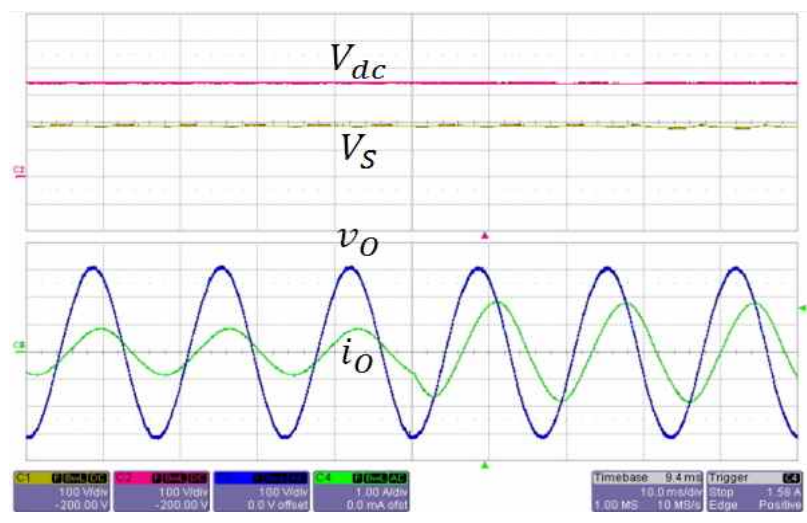

(b) $\mathrm{R}-\mathrm{L}$ 부하

그림 14 부하가 변화할 때의 실험 파형

Fig. 14 Experimental results for load change (Horizontal : $10 \mathrm{msec} /$ div., Vertical : $\left[V_{S}, V_{d c}\right.$, $\left.v_{O}\right] 100 \mathrm{~V} /$ div., $\left[i_{O}\right] 1 \mathrm{~A} /$ div.)

$\mathrm{L}=350[\mathrm{mH}]$ 에서 저항만 $100[\Omega]$ 으로 변화시킨 경우이 다. 두 경우 모두 원활하게 변화가 이루어지며 출력전류 가 증가하여도 시스템의 출력전압이 일정함을 알 수 있다.

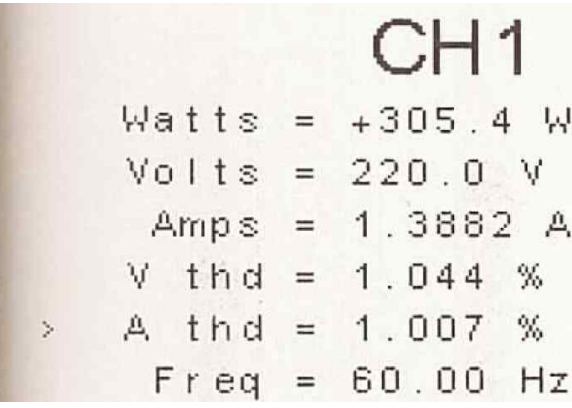

(a) 저항부하

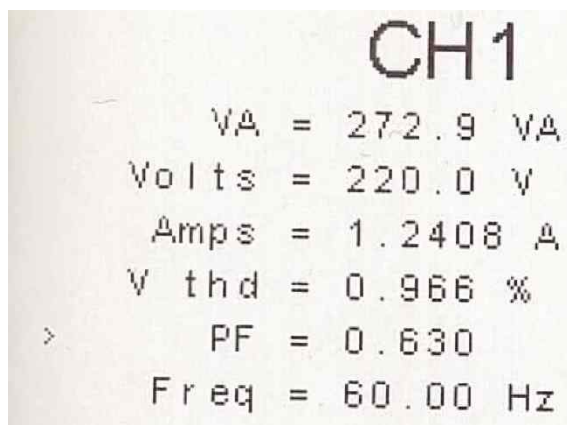

(b) R-L부하

그림 15 제안한 시스템의 출력측 계측 결과

Fig. 15 Measurement results at the output side of proposed system

그림 15는 전력분석기 PM3300을 사용하여 승압형 단 상 인버터 시스템의 출력을 측정한 결과이다. 그림 15 (a)는 저항부하일 경우로서 출력전압이 $220[\mathrm{Vrms}]$ 로 일정하며 전압 $\mathrm{THD}$ 가 $1.044[\%]$ 이다. 그림 $15(\mathrm{~b})$ 는 $\mathrm{R}-\mathrm{L}$ 부하일 경우로서 역률이 63[\%]이고 전압 $\mathrm{THD}$ 가 $0.966[\%]$ 이다. 두 경우 모두 전압 $\mathrm{THD}$ 가 5[\%] 미만으 로서 설계목표치를 만족한다.

\section{5. 결 론}

본 논문에서는 전원에 순간전압강하가 발생하면 이를 보상하여 전력의 품질을 높일 수 있는 승압형 단상 인 버터를 설계하고 구현하였다. 시스템은 부스트 변환기와 $\mathrm{PWM}$ 인버터로 구성된 시스템으로서 전원에 $0.1[\mathrm{pu}]$ 이 상의 순간전압강하가 발생하면 부스트 변환기가 동작하 여 직류링크단 전압을 승압한다. 시스템을 설계함에 있 어 시스템이 SEMI F47-0706 규격을 만족하고 출력전압 의 $\mathrm{THD}$ 가 5[\%] 미만이 되도록 하였으며 실용화를 위 하여 저가격화를 도모하였다.

부스트 변환기는 PI 제어기를 사용하여 제어하였으며, 인버터는 정지좌표계에 직접 적용이 가능하고 정상상태 오차를 제거할 수 있는 PR 제어기를 사용하여 제어하였 다. 그리고 마이크로프로세서로는 가격이 저렴한 Microchip사의 dsPIC33FJ128MC706을 사용하였다.

전력회로는 Fairchild사의 SPM인 FSBB30CH60을 사 
용하였는데 하나의 SPM으로 부스트 변환기와 인버터를 구성하여 경제성을 높였다.

설계한 시스템을 $\mathrm{R}$ 부하일 경우와 $\mathrm{R}-\mathrm{L}$ 부하일 경우에 대해 시뮬레이션하고 실험하여 시스템이 SEMI F47-0706의 요건을 만족하고 부하 변동시의 특성이 우 수함을 확인하였다. 또한 출력전압의 $\mathrm{THD}$ 가 설계 목표 치를 만족함을 확인하였다.

이 연구는 2010학년도 단국대학교 대학연구비 지 원으로 연구되었음.

\section{참 고 문 헌}

[1] A. Sundaram, "Transmission Power Quality Benchmarking Methodology", EPRI Report, 2000. 12.

[2] SEMI F47-0706:2006, "Specification for Semiconductor Processing Equipment Voltage Sag Immunity".

[3] Jing Zhou, Hui Zhou, and Zhiping Qi, "The Study on a Dual-Feed-Forward Control of DVR to Mitigate the Impact of Voltage Sags Caused by Induction Motor Starting", Proceedings of International Conference on Electrical Machines and Systems, pp. 1497-1500, 2008.

[4] 김학성, "[특집:의료기기기술] 인버터식 의료용 X-ray 전 원장치 기술동향”, 전력전자학회 학회지, 제 4 권, 제 4 호, pp. 16-19, 1998.

[5] Seung-Yong Lee, Young-Min Seo, Myeong-Soo Kim, and Soon-Chan Hong, "Boost Type Inverter System for Compensation of Voltage Sag", Proceedings of International Conference on Power Electronics ECCE Asia, pp. 2757-2762, 2011.

[6] Daniel Nahum Zmood, Donald Grahame Holmes, and Gerwich H. Bode, "Frequency-Domain Analysis of Three-Phase Linear Current Regulators", IEEE Transactions on Industry Applications, Vol. 37, No. 2. 2001.

[7] Alejandro G. Yepes, Jesus Doval-Gandoy, Jano Malvar, Francisco D. Freijedo, Oscar Lopez, and Pablo Fernandez-Comesana, "Effects of Discretization Methods on the Performance of Resonant Controllers", IEEE Transactions on Power Electronics, Vol. 25, No. 3, 2003.

[8] Cartinhour and Jack, Digital Signal Processing, Prentice-Hall, 1999.

[9] 홍순찬, 전희종, 윤용수, 전력전자공학, (주)한국맥그로힐, 2011.

[10] Hyosung Kim and Seung-Ki Sul, "A Novel Filter Design for Output LC Filters of PWM Inverters", Journal of Power Electronics, Vol. 11, No. 1, 2011.

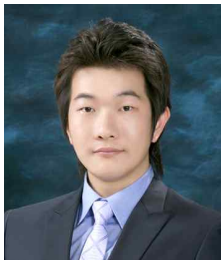

이승용(李承容)

1984년 9월 30일생. 2010년 단국대 전자컴 퓨터공학부 졸업. 현재 동 대학원 전자전기 공학과 석사과정.

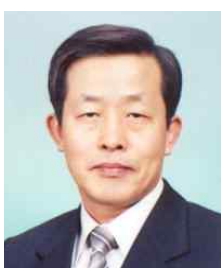

홍순찬(洪淳瓚)

1950년 2월 24일생. 1973년 서울대 전기공 학과 졸업. 1975년 동 대학원 전기공학과 졸업(석사). 1985년 동 대학원 전기공학과 졸업(공박). 1975년 1978년 해군사관학교 교수부 전기공학실 전임강사. 1978년 현 재 단국대 전자전기공학부 교수. 1986년 1987년 미국 텍사스 A\&M 대학교 방문교수. 1997년 2000년 대한전기학회 이사. 2002년 당 학회 회장. 2002년 2005년 단국대 공과대학 학장. 